\title{
APPLE ORCHARD MANAGEMENT PRACTICES AFFECT MICROBIAL POPULATIONS ON LEAVES AND FRUIT
}

\author{
M. WALTER ${ }^{1}$, K.S.H. BOYD-WILSON ${ }^{1}$, F.O. OBANOR ${ }^{1}$, \\ P.A. ALSPACH ${ }^{2}$, R.R. MARSHALL ${ }^{3}$, C.M. FRAMPTON ${ }^{4}$ and N.W. WAIPARA ${ }^{5}$ \\ ${ }^{1}$ HortResearch, P.O. Box 51, Lincoln, New Zealand \\ ${ }^{2}$ HortResearch, P.O. Box 220, Motueka, New Zealand \\ ${ }^{3}$ HortResearch, RD 1, Earnscleugh Road, Alexandra, New Zealand \\ ${ }^{4}$ Christchurch School of Medicine, P.O. Box 4345, Christchurch, New Zealand \\ ${ }^{5}$ Landcare Research, Private Bag 92170, Auckland, New Zealand
}

Corresponding author:mwalter@hortresearch.co.nz

The effect of apple orchard management on epiphytic, microbial populations on apple leaves and fruit was investigated during the 2001/2002 and 2002/2003 growing seasons. Leaves and fruit were collected from certified organic (Bio-Gro) and IFP (Integrated Fruit Production) managed apple orchards in spring and autumn from four New Zealand sites (Hawke's Bay, Nelson, Canterbury and/or Central Otago) for cvs Braeburn and Fuji. Micro-organisms were recovered by washing in phosphate buffer using a stomacher blender. Culturable epiphytes were enumerated using serial plate dilutions. Micro-organisms were also separated into recognisable taxonomic units (RTUs) based on colony morphology. Data were analysed for abundance, dominance, richness, evenness and general diversity for all micro-organisms, as well as grouped into bacteria, yeasts and other fungi. For all analyses across microbial population groups, regions, seasons, years, tissue types and cultivars the general trend observed was that microbial population groups on leaves and fruit of Bio-Gro orchards harboured more micro-organisms and a higher species richness than IFP orchards.

\section{RELATIONSHIPS BETWEEN PEAR FRUIT SURFACE BOTRYTIS CINEREA AND PENICILLIUM EXPANSUM SPORE LEVELS AND FRUIT DECAY}

\author{
R.A. SPOTTS ${ }^{1}$, M. SERDANI ${ }^{1}$, M. WALTER ${ }^{2}$ and P. HARRIS-VIRGIN ${ }^{3}$ \\ ${ }^{1}$ Mid-Columbia Agricultural Research and Extension Center, Oregon, USA \\ ${ }^{2}$ HortResearch, PO Box 51, Lincoln, New Zealand \\ ${ }^{3}$ HortResearch, PO Box 220, Motueka, New Zealand \\ Corresponding author:mwalter@hortresearch.co.nz
}

The objective of this research was to study the relationships between grey mould (Botrytis cinerea) and blue mould (Penicillium expansum) decay developing in cold storage with fruit surface populations of $B$. cinerea and $P$. expansum. Bosc pears were harvested from six orchards in Motueka, New Zealand, in 2004. Surface populations of decay fungi were determined by dilution plating and real time PCR. Fruit were stored at $-0.5^{\circ} \mathrm{C}$ and evaluated for decay after three and six months. Grey mould ranged from 0.1 to $1.4 \%$, and differences in the incidence between orchards were significant $(\mathrm{P}=0.02)$. Significant relationships were observed between grey mould and population (colony forming units $/ \mathrm{ml})$ of $B$. cinerea $(\mathrm{P}=0.03)$ and DNA of $B$. cinerea on the fruit surface $(\mathrm{P}=0.08)$. There were no significant differences in blue mould between orchards. The quantity of spores of $B$. cinerea on the fruit surface appeared to be a good predictor of decay. Dilution plating results are not available for several days, but DNA analysis can be completed the same day that fruit are harvested. Using spore numbers on the fruit surface should allow ranking of orchards according to decay risk potential in any given year. 